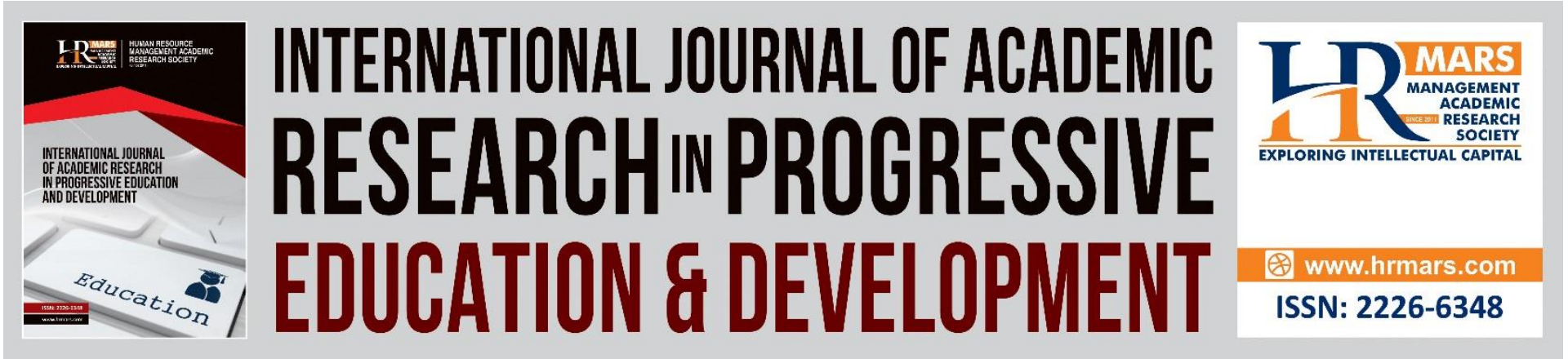

\title{
Pronunciation Errors of Arabic Consonants among Chinese Students in Gansu, China
}

Ma Yalan, Mohd Azidan Bin Abdul Jabar, Ng Chwee Fang

To Link this Article: http://dx.doi.org/10.6007/IJARPED/v10-i3/10437

DOI:10.6007/IJARPED/v10-i3/10437

Received: 02 June 2021, Revised: 28 June 2021, Accepted: 20 July 2021

Published Online: 22 August 2021

In-Text Citation: (Yalan et al., 2021)

To Cite this Article: Yalan, M., Jabar, M. A. B. A., \& Fang, N. C. (2021). Pronunciation Errors of Arabic Consonants among Chinese Students in Gansu, China. International Journal of Academic Research in Progressive Education and Development, 10(3), 844-854.

Copyright: (C) 2021 The Author(s)

Published by Human Resource Management Academic Research Society (www.hrmars.com)

This article is published under the Creative Commons Attribution (CC BY 4.0) license. Anyone may reproduce, distribute, translate and create derivative works of this article (for both commercial and non-commercial purposes), subject to full attribution to the original publication and authors. The full terms of this license may be seen

at: http://creativecommons.org/licences/by/4.0/legalcode

\section{Vol. 10(3) 2021, Pg. 844 - 854}

Full Terms \& Conditions of access and use can be found at http://hrmars.com/index.php/pages/detail/publication-ethics 


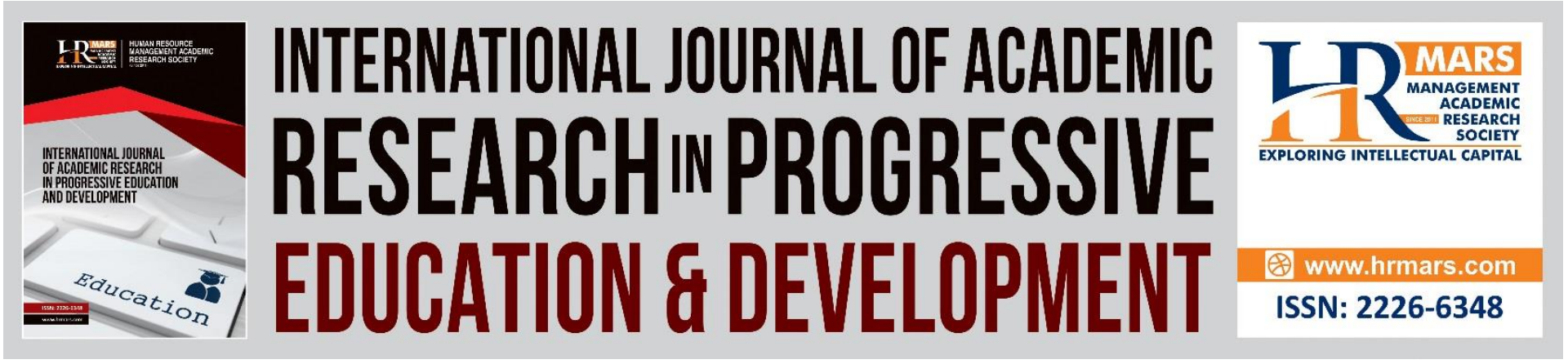

\title{
Pronunciation Errors of Arabic Consonants among Chinese Students in Gansu, China
}

\author{
Ma Yalan, Mohd Azidan Bin Abdul Jabar, Ng Chwee Fang \\ Faculty of Modern Language and Communication, University Putra Malaysia \\ Email: 591156777@qq.com
}

\begin{abstract}
The study illustrates the similarities and differences between Arabic and Chinese phonetic systems through comparison. The study aims to explore the pronunciation errors of Arabic consonants among Chinese students learning Arabic and the reasons behind the pronunciation errors. The study found that Chinese students tend to make consonants, finding it easy to pronounce $ه / \mathrm{h} /$ as $\mathrm{h} / \mathrm{x} /$ or $\mathrm{C} / \mathrm{h} /$. Ultimately, the study could improve Chinese students' comprehensive understanding of the Arabic phonetic system and avoid similar errors in learning consonants.
\end{abstract}

Keywords: Arabic Consonants, Pronunciation, Chinese Students, Errors

\section{Introduction}

Pronunciation is vital in foreign language learning as it directly affects learners' communicative competence and performance. Although intelligible pronunciation is an integral part of communicative competence, pronunciation is a neglected aspect of language teaching and learning. Significantly, learners with imperfect pronunciation skills cannot communicate effectively (Ikhsan, 2017). Sabouri stated that "Language is primarily a means of communication, and this communication needs to be understood by all, so teaching pronunciation should be a priority. If you do not pay attention to the common pronunciation, there is a risk that the subject will not understand" (Gilakjani \& Sabouri, 2016).

Arabic is one of the oldest languages, a Semitic language with many differences compared to Sino-Tibetan languages such as Chinese. Some of the differences include unique phonemes and phonetic features and a complicated morphological word structure. Furthermore, Arabic is a Semitic language with numerous differences from other languages, including unique phonemes, phonetic features, and complicated morphological word structure (Schiff \& Saiegh-Haddad, 2018). Arabic also has 34 phonemes comprising three short vowels (/i/, /a/, /u/), three long vowels (/i:/, /a:/, /u:/ which are the counterparts of the short vowels), and 28 consonants (Jassem, 2016). Meanwhile, Chinese Mandarin has 26 consonants, with only four tones and a neutral tone, which is rarely seen in tone errors (Hao \& Liu, 2019). Consequently, Chinese students face difficulty in learning Arabic as a second language.

For Arabic teaching in Chinese universities, pronunciation lessons are only six to eight weeks from entry. Besides, some teachers make little effort to teach pronunciation overtly 
and only give attention briefly. Additionally, the strengthening of the global character of language caused many Chinese teachers to realise the importance of Arabic grammar and vocabularies overshadowed by the desire to sound intelligible. Correct pronunciation enables people to understand the speaker easier, whereas incorrect pronunciation causes misunderstanding between the speaker and the listener (Levis, 2006). Moreover, a clear and correct pronunciation could form effective communication, regardless of inaccurate applications of grammar and vocabulary. Ikhsan stated that regardless of good vocabulary and grammar, a mispronunciation will cause misunderstanding between the speaker and the listener, and an unclear pronunciation will not produce good communication (Ikhsan, 2017).

\section{Literature Review}

In the phonological system, Chinese and Arabic are two distinct languages with common and distinctive phonological features. The distinctive features are found in the phonemic alphabet, such as consonants and vowels or the phonetic rules. The Arabic sound system is rich in consonant sounds and has a limited vocalic system, distinguished as a Semitic language. Moreover, Arabic depends on consonants, not on vowels. Specifically, the consonantal system includes a class (group) of sounds pronounced between the larynx and the upper pharynx, such as glottal or laryngeals, pharyngeal and uvular fricative sounds. / $h, ?, \hbar, \varepsilon, x, \gamma /$ as well as / $d, d, r, t, s$, that have a velarisation.

Hijaazi classifies the Arabic sounds similar to Arabic linguists, declaring that there are 34 Arabic sounds, with 28 consonants as he does not consider / $\mathbf{I}$ as a phoneme and six are vowels. The ancient Arabic phonetics and linguists interested in the phonetic system of the Arabic language reflected an early, accurate and comprehensive understanding of the nature of speech and the speech organs. The sounds of Arabic were studied as the mother tongue and described precisely, constructing the rules of these sounds, the characteristics and their interrelationships.

Chinese phonology has been studied for over 1,700 years since the first rhyming books in the third century. The phonology of Mandarin Chinese comprises initials (consonants), finals (vowels), and tones. Nevertheless, linguists and scholars have debated the number of Mandarin consonant sounds. Some authors agree that Mandarin consonant sounds are 21, whereas others disagree, stating only 19 exist. According to Burling, "Standard Chinese has 19 consonants. Additionally, there are three palatals and some syllabic consonants" (Post \& Burling, 2017). Eme stated, "The consonants of Chinese comprise six plosives, two nasals, five fricatives, six affricates, one lateral approximant and these sum up to 21 consonants". The current study followed Eme, presenting 21 consonant sounds of Mandarin (Eme \& Uba, 2016).

Although errors relate to mistakes, both differ. Distinguishing between errors and mistakes is vital as most people still misunderstand the definition of both. Accordingly, Istiana stated that mistake is less serious as it is the retrieval that is faulty, not the knowledge (Istiana, 2017). Hence, the students know the rule, but they make a slip when producing it. Besides, Istiana provided a different meaning, stating that a mistake refers to a performance error, either a random guess or a slip (Istiana, 2017). Thus, a mistake is a failure to utilise a known system correctly. Everyone makes mistakes in native and second language situations.

Meanwhile, Istiana mentioned that errors are caused by lack of knowledge or incorrect hypotheses about the target language, whereas mistakes are due to temporary lapses of memory, confusion, slips of the tongue and others. Another way to differentiate between error and mistake is if the learners can correct themselves, it is probably a mistake, but if they 
cannot, it is an error (Istiana, 2017). Phonology is the material shell and means of expression of language, and the material foundation of the existence and development of language (Cheng et al., 2018). Therefore, pronunciation is how a person utters a word or language, to express language when people communicate. Gilakjani mentioned that pronunciation is the way of uttering a word in an accepted manner and a set of habits of producing a sound (Gilakjani, 2016).

Afshari and Ketabi (2017) reported the importance of pronunciation as a key element of learning oral skills in a second language. Furthermore, Maldonado (2018) highlighted that pronunciation is a difficult area for learners and teachers. Istiana (2017) stated that pronunciation is the most prominent and unavoidable marker of a language learner's proficiency. The comprehensibility and intelligibility of the spoken language are highly dependent on its pronunciation (Darcy, 2018). If the word is not pronounced correctly, the content of the discussion will become meaningless. The direct effects of pronunciation on learners' communicative competency make it an integral part of second/foreign language learning and performance (Osmany, 2017).

Table 1

Theoretical Framework

L1 L2

(Chinese language) (Arabic language)

Step 1 Description

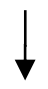

D1 D2

(Describe Chinese) (Describe Arabic)

Step 2 Selection

Step 3 Contrast

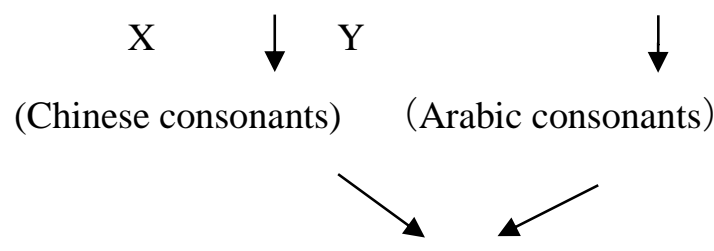

$\mathrm{X} / \mathrm{Y}$

(Contrasting Chinese and Arabic Consonants)

Step 4 Prediction

$\mathrm{P}$

Step 5 Test

$\mathrm{T}$ 
1. Select two languages ( $L 1$ and $L 2$ ) and description of the two languages.

2. A selection of forms to be contrasted.

3. Contrast selected forms L1 and L2.

4. Predict the outcomes.

5. Testing the predictions

According to the model, the first procedure was conducted in the first chapter: selecting Arabic as LI and Chinese as L2 and describing both languages. The second procedure is selecting a form to be contrasted. The study showed that the choice of form to be contrasted is the consonants. The third and fourth procedures involved contrasting, predicting and testing the difficulty of the Arabic to Chinese consonants, conducted in chapters three and four. The models apply to any set of languages with any form of linguistic units required to be contrasted. Therefore, the study is highly useful for contrasting languages such as Arabic and Chinese and other languages.

\section{Methodology}

The study selected the descriptive qualitative method and used a percentage to make a simple calculation of the pronunciation error rate of Arabic consonant letters by Chinese students to provide a clear result. Based on the theoretical framework, the study designed research methods to implement the fifth step of the test, verifying the fourth step prediction, identifying consonants sound pronounced errors and analysed factors of consonants pronounced incorrectly by the Chinese students. Moreover, the study was conducted at the Northwest Normal University (NNU), Arabic Departments on the first year second-semester students.

The samples comprised 30 Chinese undergraduate students from similar educational backgrounds, chosen randomly from 60 students in Arabic Class 1. First, 60 students were divided into two groups according to gender, the names of all students were written on paper and placed in boxes. Next, a teacher randomly selected 15 males and 15 females from the box as test samples. Hence, 30 people were selected from the 60 people in the class as the study sample.

Data collection is essential in a research design. Hence, the study used interviews and recording tests to collect raw data. The interviews involved participants answering questions face to face while an oral quiz recorded the sound for Chinese students. The information was obtained from the students. Additionally, the study utilised two data collection instruments: 1) student voice recordings and 2) student interviews. For the first one, the students had to read 28 sentences with 28 words to be evaluated. The voice recording results were evaluated by two evaluators, one native and one non-native teacher. Therefore, the qualitative data comprised of voice recordings and the analysis of the evaluators. Ten questions were prepared for the structured interview conducted with 30 students for the second data collection instrument. The interview questions were developed meticulously to identify why students of the first semester of NNU will make mistakes in learning Arabic.

The recording is intended to obtain data about the percentage of each type of pronunciation errors. From the recording, the teacher would know what pronunciation errors are often found in students Arabic pronunciation. Additionally, pronunciation errors were 
assessed by a native Arabic teacher from Egypt. The percentage is calculated as follows: in the $ض / d^{r} /$ sound test, the total number of students with test pronunciation of (30), the number of students who pronounce correctly is (14), and the number of students who pronounce incorrectly is (16). Therefore, the following calculates the percentage of students with correct pronunciation in $ض / d^{r} /$ sound:

(1) No. of students with correct pronunciation $=14 / 30 \times 100=46.6 \%$

The above calculation indicates that only $46.6 \%$ of learners could pronounce the $ض / d^{r} /$ sound correctly. Meanwhile, the following presents the percentage of the students with incorrect pronunciation:

(2) Students with incorrect pronunciation $=16 / 30 \times 100=53.3 \%$

Observably, $53.3 \%$ of the students could not pronounce the $ض / d^{r} /$ sound correctly.

\section{Results}

The students were asked ten questions about their views towards factors of pronunciation errors and the degree of application. When asked the following question (Have you known or studied Arabic before? When did you begin to learn Arabic?), 28 students had negative answers for both. The students are first-timers in the Arabic major and started learning Arabic after finishing high school and entering university. Nevertheless, only two students accepted the second foreign language training institutions from outside in an amateur study. Therefore, the students lack specialised learning in Arabic pronunciation.

When asked the following question (Did you receive training on pronunciation in class? If yes, how long? Do you think that was sufficient to qualify you to pronounce well?), all students confirmed taking one course in phonetics in the first semester as a basic course. As for the Ministry of Education courses, the students said that two basic courses in pronunciation were held during their first semester: one focused on 28-letter recognition and pronunciation for students with no Arabic language foundation and the other involved Arabic words and sentence reading. The courses were taught by foreign teachers (Arabic as mother tongue and Chinese teachers).

Nonetheless, the courses were insufficient to qualify the students to pronounce well. The students were dissatisfied with the period of pronunciation teaching, stating that the first stage of pronunciation teaching was only four to six weeks. At the end of the courses, most students had a low level of pronunciation of each letter. Notably, the subsequent courses began to focus on grammar, vocabulary and sentence pattern, but the correctness of pronunciation was ignored.

When asked the following question (Do you seek opportunities to communicate in Arabic whenever possible?), 12 interviewees mentioned attempting to find opportunities to communicate in Arabic. When asked why, they stated that they wanted to make their pronunciation closer to the native speaker when learning Arabic. The students were exempted from the trouble of correcting again due to incorrect pronunciation. Contrarily, the other 15 respondents indicated no such opportunity and no attempt to find it. The latter view that the 
accuracy of Arabic consonant pronunciation is not important for learning, focusing on grammar and syntax learning.

When asked the following question (Are there any native Arabic speakers around you? If yes, would you often communicate with them in Arabic?). The interviewees gave the opposite answer, with six of them admitting that they had Arabic-speaking friends. When asked specifically about who these people are, the students answered the same. These people were international students in the Arabic-speaking countries of the Middle East. Moreover, the students admitted willingness to use Arab and foreign exchanges with the Arabic-speaking international students to practice listening and speaking. Only two students regularly meet with these international students while the other 24 students think only of the foreign teachers hired by the school, and no one else can communicate in Arabic.

When asked the following question (Do you believe you have a problem with pronunciation? If yes, what are the potential reasons?). The interviewed students confirmed the challenge and difficulty associated with pronunciation. When asked about the potential reasons for this weakness in pronunciation, the outlined reasons are 1 . Arabic teachers deemphasise or focus less on pronunciation, 2. The Arabic phonological system is complex, 3 . Many letters in Arabic are difficult for Chinese students in terms of pronunciation and writing habits, 4. Chinese students are indifferent or careless about the language component, 5. Arabic teachers also contribute to the problem as their pronunciation is generally faulty, inappropriate, or inadequate. Students tend to imitate their teachers and produce the same errors as their teachers, and 6 . The issue of transfer decisively triggers errors in pronunciation. Chinese students rely on Chinese when pronouncing Arabic words.

When asked the following question (Do you think your native or dialect pronunciation habits affect your practice of pronouncing Arabic consonants?). All 30 respondents believed that their mother tongue and dialect would affect their Arabic pronunciation, specifically consonant pronunciation, which was mainly reflected in the pronunciation part and habitual pronunciation.

When asked the following question (Do you often look for Arabic tapes or radios to practice after class? and How long?). Generally, ten students spend about half an hour a day listening to Arabic audio materials while eight students listen to Arabic audio materials twice a week, between half an hour and an hour. The other 12 students do not listen to Arabic audio every day, only occasionally listening to the audio. Nevertheless, the students said their listening materials were limited to reading the texts corresponding to the textbooks. The university did not provide other materials, and it was difficult to find extra-curricular tapes.

When asked the question (What is the model in pronunciation for you?). they stated that the model is their teachers even if their pronunciation was inaccurate. Secondly, the pronunciation of the foreign teacher is a model, but the course of the foreign teacher is short.

When asked the following question (What can you do to improve the accuracy of Arabic consonants? Have you mastered all the pronunciation rules that the teacher taught you in class?), all students stated that two ways to improve the accuracy of Arabic speech: 1 . Correct the teacher's pronunciation by listening to it when reading the sentence or reading the text, 
then imitate, and let the teacher correct the mistake in the classroom; 2 . Correct and improve pronunciation by recording materials that match the corresponding materials, then imitate the pronunciations. Four students confidently admitted to fully mastering the consonant pronunciation methods and practice methods taught by the Arabic foreign teachers in the classroom and will follow these methods to practice actively while the other 26 students stated not fully mastering the Arabic letter pronunciation.

When asked the following question (What do you think is the most critical problem in practising Arabic pronunciation? Do you have any questions about the Arabic phonology system?), all students were hesitant. The 30 students were asked by the interviewer what the Arabic phonology system is? After being specifically explained by the interviewer, they stated not specifically learning the content. In their opinion, the issue in practising Arabic pronunciation is the willingness to read the text to practise the pronunciation but not knowing whether their pronunciation is correct.

The test aims to identify the pronunciation errors among Chinese students learning Arabic when speaking or reading the language. Hence, 28 words were chosen randomly, but each word contains a sound, which could be pronounced incorrectly by the Chinese students learning Arabic. The test included 28 Arabic consonant sounds and the words were formed in sentences; each sentence contained one target sound, and each student was asked to read all the sentences aloud while being recorded. At the end of the process, the errors were written on paper, tabulated, and analysed statistically and descriptively. 
INTERNATIONAL JOURNAL OF ACADEMIC RESEARCH IN PROGRESSIVE EDUCATION AND DEVELOPMENT

Vol. 10, No. 3, 2021, E-ISSN: 2226-6348 @ 2021 HRMARS

Table 2

The pronunciation of Arabic consonants by the NNU students

\begin{tabular}{|c|c|c|c|c|c|c|}
\hline Word & TS & NS & NSC & $\%$ & $\mathrm{NSI}$ & $\%$ \\
\hline مقابل & ب/b/ & 30 & 28 & $93.3 \%$ & 2 & $6.7 \%$ \\
\hline يمضي & ض/d'/ & 30 & 15 & $50 \%$ & 15 & $50 \%$ \\
\hline كثير & sf /k/ & 30 & 27 & $90 \%$ & 3 & $10 \%$ \\
\hline حديقة & ق/q/ & 30 & 18 & $60 \%$ & 12 & $40 \%$ \\
\hline نشاء & $s / P /$ & 30 & 23 & $76.6 \%$ & 7 & $23.4 \%$ \\
\hline الاستمارة & م/m/ & 30 & 29 & $96.6 \%$ & 1 & $3.4 \%$ \\
\hline الناس & ن /n/ & 30 & 29 & $96.6 \%$ & 4 & $3.4 \%$ \\
\hline رجالا & ج/d3/ & 30 & 19 & $63.3 \%$ & 11 & $36.7 \%$ \\
\hline لطيف & ف/f/ & 30 & 27 & $90 \%$ & 5 & $10 \%$ \\
\hline أظهر & ظ/ðฯ/ & 30 & 12 & $40 \%$ & 18 & $60 \%$ \\
\hline الإصلاح & ص/s's/ & 30 & 16 & $53.3 \%$ & 14 & $46.7 \%$ \\
\hline الشوارع & / / / / & 30 & 21 & $70 \%$ & 9 & $30 \%$ \\
\hline غرفتي & $\dot{\varepsilon} / \mathrm{X} /$ & 30 & 12 & $40 \%$ & 18 & $60 \%$ \\
\hline العشاء & $\varepsilon / \varsigma /$ & 30 & 17 & $56.6 \%$ & 13 & $43.4 \%$ \\
\hline لنذهب & ه/h/ & 30 & 22 & $73.3 \%$ & 8 & $26.7 \%$ \\
\hline الروايات & $g / w /$ & 30 & 24 & $80 \%$ & 6 & $28 \%$ \\
\hline الأشياء & ي/j/ & 30 & 25 & $83.3 \%$ & 5 & $16.7 \%$ \\
\hline أحوال & J/I/ & 30 & 22 & $73.3 \%$ & 8 & $26.7 \%$ \\
\hline السيارة & $\mathrm{J} / \mathrm{r} /$ & 30 & 15 & $50 \%$ & 15 & $50 \%$ \\
\hline آثار & ث/O/ & 30 & 20 & $66.6 \%$ & 10 & $33.4 \%$ \\
\hline الأحذية & $\dot{ذ} /$ /ठ & 30 & 17 & $56.6 \%$ & 13 & $43.4 \%$ \\
\hline سافرت & س /s/ & 30 & 19 & $63.3 \%$ & 21 & $36.7 \%$ \\
\hline المنزل & $j / z /$ & 30 & 23 & $76.6 \%$ & 7 & $23.4 \%$ \\
\hline أخرى & $\dot{\tau} / x \mid$ & 30 & 13 & $43.3 \%$ & 17 & $56.7 \%$ \\
\hline البحر & $\tau / \hbar /$ & 30 & 18 & $60 \%$ & 12 & $40 \%$ \\
\hline تتاح & ت/t/ & 30 & 28 & $93.3 \%$ & 2 & $6.7 \%$ \\
\hline عدد & $\mathrm{s} / \mathrm{d} /$ & 30 & 22 & $73.3 \%$ & 8 & $26.7 \%$ \\
\hline الطابق & $b / t^{\varsigma} /$ & 30 & 12 & $40 \%$ & 18 & $60 \%$ \\
\hline
\end{tabular}

Note: TS = target sound; NS = number of students; NSC = number of students with correct pronunciation; NSI = number of students with incorrect pronunciation.

Based on the results above, most NNU students incorrectly pronounced Arabic consonants that are not present in the Chinese language and other consonants.

\section{Conclusion}

The researcher concludes that the second-semester students of NNU Arabic Class 1 produced many errors in their Arabic pronunciation and consonants. The problem of pronouncing Arabic words and consonants are explained as follows: 
1. Generally, Chinese students have a high degree of mastery of the seven pairs of consonants

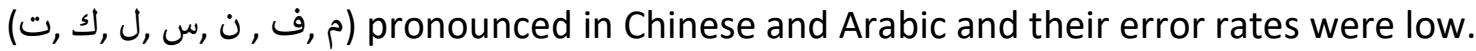

2. From the eight pairs of similarly pronounced letters, the pronunciation error rate was higher, mainly due to the pronunciation of similar letters in the students' mother tongue. The pronunciation of Chinese letters was used to replace the Arabic letters.

3. For the Chinese students, the letters with a high Arabic pronunciation error rate were concentrated in the Arabic letters that do not exist in Chinese, especially the pharyngeal. Chinese students tend to pronounce $\mathrm{s} / \mathrm{j} /$ into i/i/, g/w/ into $\mathrm{u} / \mathrm{u} /, \mathrm{s} / \mathrm{h} /$ into $\mathrm{h} / \mathrm{x} /$ or $ح / \hbar /, \dot{\varepsilon} / \mathrm{x} /$

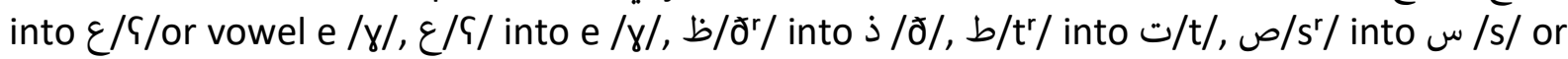

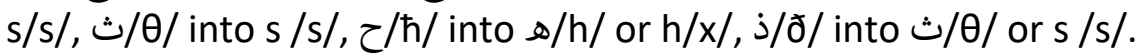

The pronunciation errors are caused by various factors, such as being affected by the language habits of the students' mother tongue or the surrounding language environment. Besides, no special course on the Arabic phonetic system is available.

The main significance of this research is the possibility to improve Chinese students' pronunciation skills, especially in consonants. Adding many benefits to students, teachers and further researcher. For students, students can understand the difficulties and mistakes in the process of learning Arabic pronunciation. Learners need to understand there is an error, then know precisely where it is, what it is, and then how to produce it accurately. After that they will try to eliminate their pronunciation errors so that they can improve the pronunciation of their Arabic words, learning as much as possible about these easy-to-speak wrong letters to avoid making mistakes again in the future. For the Arabic teacher, this study can clearly understand the difficulties and problems students have in learning Arabic pronunciation. Therefore, teachers need to explain how they hear what the learner is saying and help to compare and contrast the difference between what they said and what they wanted to say. In order to teach Arabic language to Chinese students in the teaching process, the teacher will design and improve more pronunciation teaching methods, by changing teaching methods, teaching focus. By appropriately changing the method of class, students are more likely to master Arabic pronunciation at the basic stage. For the other researchers this research can be used as material consideration if she/he will investigate the same subject. So that ways, the researcher tries to give the best contributions.

\section{Acknowledgement}

First and foremost, my utmost gratitude goes to Allah. The study would never have come into reality without His grace and protection.

Upon the completion of the thesis, I would like to take this opportunity to express my deep gratitude to my supervisor, Prof. Dr Mohd Azidan Bin Abdul Jabar, who has offered me constructive guidance for the planning of the thesis and invaluable advice and encouragement for its completion and improvement, which is of great value to my future academic life. Although busy in his teaching and research, he is a highly devoted teacher and never hesitates to offer timely and spiritual support. He spares no effort to read, comment on and polish my thesis. Without his help and encouragement, my thesis would have been impossible.

Besides, I wish to extend my sincere gratitude to my co-supervisor, Dr Ng Chwee Fang, who have taught me and given me selfless support during my three postgraduate years. It is my great honour to have known all those respectable teachers. It has been a privilege knowing and working with them. 
Furthermore, I am deeply indebted to my beloved family mother--Ma HuiFeng and my boyfriend--Qi WenJie. Because of their love, care, understanding and encouragement, I can complete my thesis writing eventually.

Finally, I wish to express my gratitude to the teachers who helped me at NNU China and the students who helped me complete the research. They are an important guarantee for my thesis and research.

\section{References}

Afshari, S., \& Ketabi, S. (2017). Current Trends and Future Directions in Teaching English Pronunciation. International Journal of Research Studies in Language Learning, 6(2), 8391.

Cheng, G., Cao, Y., Zhang, C., Jiang, Z., Yu, Y., \& Mohanty, M. K. (2018). Application of Novel Flotation Systems to Fine Coal Cleaning. International Journal of Coal Preparation and Utilization, 1-13.

Darcy, I. (2018). Powerful and Effective Pronunciation Instruction: How Can We Achieve It? Catesol Journal, 30(1), 13-45.

Eme, C. A., \& Uba, E. D. (2016). A Contrastive Study of the Phonology of Lgbo and Yoruba. UJAH: Unizik Journal of Arts and Humanities, 17(1), 65-84.

Gilakjani, A. P. (2016). What Factors Influence the English Pronunciation of EFL Learners? Modern Journal of Language Teaching Methods, 6(2), 315.

Gilakjani, A., \& Sabouri, N. B. (2016). How Can Students Improve their Reading Comprehension Skill. Journal of Studies in Education, 6(2), 229-240.

Hao, Y. C., \& Liu, J. L. C. (2019). The Effects of Tone Training on Tone Perception Accuracy in Chinese Language Classrooms. Classroom Research on Chinese as a Second Language, 21.

Ikhsan, M. K. (2017). Factors Influencing Students' Pronunciation Mastery at English Department of Stkip Pgri West Sumatera. Al-Ta lim Journal, 24(2), 110-117.

Istiana, N. (2017). English Pronunciation Errors by the Seventh Grade Madurese Students (Doctoral dissertation, Widya Mandala Catholic University Surabaya).

Jassem, Z. A. (2016). The Arabic Origins of English and Indo-European "Definite Articles": A Radical Linguistic Theory Approach. International Journal of English Language, Literature and Humanities 4, 6, 530-55.

Levis, J. M. (2006). Pronunciation and the Assessment of Spoken Language. In Spoken English, TESOL and Applied Linguistics (pp. 245-270). Palgrave Macmillan, London.

Maldonado, M. A. (2018). Pronunciation. What Rioplatense Spanish Speaking EFL Teachers Need to Know. SADRŽAJ/Table of Contents, 16, 85-98.

Osmany, S. (2017). Factors Affecting Teaching Pronunciation at Tertiary Level: A Case Study (Doctoral dissertation, East West University).

Post, M. W., \& Burling, R. (2017). The Tibeto-Burman Languages of Northeast India. The SinoTibetan Languages, 213-242.

Schiff, R., \& Saiegh-Haddad, E. (2018). Development and Relationships between Phonological Awareness, Morphological Awareness and Word Reading in Spoken and Standard Arabic. Frontiers in Psychology, 9, 356. 